\title{
Efficacy and effectiveness of on- versus off-pump coronary artery bypass grafting: A meta-analysis of mortality and survival
}

\author{
Giovanni Filardo, PhD, MPH, ${ }^{\mathrm{a}, \mathrm{c}, \mathrm{d}}$ Baron L. Hamman, MD, ${ }^{\mathrm{e}}$ Briget da Graca, JD, MS, ${ }^{\mathrm{b}, \mathrm{c}}$ \\ Danielle M. Sass, MPH, CPH, ${ }^{\text {a }}$ Natalie J. Machala, MBA, ${ }^{a}$ Safiyah Ismail, BS, ${ }^{a}$ \\ Benjamin D. Pollock, PhD, MSPH, ${ }^{\mathrm{a}, \mathrm{c}}$ Ashley W. Collinsworth, ScD, MPH, ${ }^{\mathrm{b}, \mathrm{c}}$ and Paul A. Grayburn, MD
}

\section{ABSTRACT}

Background: Despite many studies comparing on- versus off-pump coronary artery bypass graft $(\mathrm{CABG})$, there is no consensus as to whether one of these techniques offers patients better outcomes.

Methods: We searched PubMed from inception to June 30, 2015, and identified additional studies from bibliographies of meta-analyses and reviews. We identified 42 randomized controlled trials (RCTs) and 31 rigorously adjusted observational studies (controlling for the Society of Thoracic Surgeons-recognized risk factors for mortality) reporting mortality for off-pump versus on-pump CABG at specified time points. Trial data were extracted independently by 2 researchers using a standardized form. Differences in probability of mortality (DPM) were estimated for the RCTs and observational studies separately and combined, for time points ranging from 30 days to 10 years.

Results: RCT-only data showed no significant differences at any time point, whereas observational-only data and the combined analysis showed short-term mortality favored off-pump CABG ( $\mathrm{n}=1.2$ million patients; $36 \mathrm{RCTs}, 26$ observational studies; DPM [95\% confidence interval (CI)], $-44.8 \%$ [-45.4\%, $-43.8 \%$ ]) but that at 5 years it was associated with significantly greater mortality ( $\mathrm{n}=60,405$ patients; 3 RCTs, 5 observational studies; DPM [95\% CI], 10.0\% $[5.0 \%, 15.0 \%])$. At 10 years, only observational data were available, and offpump CABG showed significantly greater mortality (DPM [95\% CI], 14.0\% $[11.0 \%, 17.0 \%])$.

Conclusions: Evidence from RCTs showed no differences between the techniques, whereas rigorously adjusted observational studies (with $>1.1$ million patients) and the combined analysis indicated that off-pump CABG offers lower short-term mortality but poorer long-term survival. These results suggest that, in real-world settings, greater operative safety with off-pump CABG comes at the expense of lasting survival gains. (J Thorac Cardiovasc Surg 2018;155:172-9)

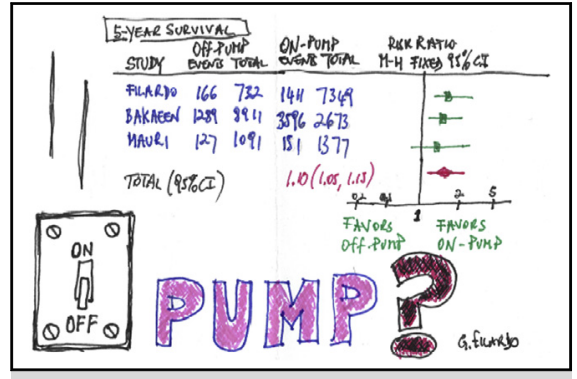

Does off- or on-pump CABG offer patients better chances of survival?

\section{Central Message}

Evidence from randomized controlled trials showed no differences between on- versus off-pump coronary artery bypass graft surgery, but rigorously-adjusted real-world data indicated that off-pump coronary artery bypass graft surgery offers lower short-term mortality but poorer long-term survival.

\section{Perspective}

Many studies have compared outcomes of off- and on-pump coronary artery bypass graft surgery (CABG), reporting inconsistent results. Here, a comprehensive picture of the evidence comparing on- and off-pump CABG (both randomized controlled trials and rigorously adjusted observational studies) suggests that, in real-world settings, off-pump CABG may offer greater operative safety but at the expense of lasting survival gains.

See Editorial Commentary page 180.
An estimated 800,000 people undergo coronary artery bypass graft (CABG) surgery worldwide each year. ${ }^{1}$ Off-pump CABG, which was introduced in the 1980s to

From the ${ }^{\mathrm{a}}$ Department of Epidemiology, and ${ }^{\mathrm{b}}$ Center for Clinical Effectiveness, Baylor Scott \& White Health, Dallas; ${ }^{\mathrm{c}}$ Robbins Institute for Health Policy and Research, Baylor University, Waco; ${ }^{\mathrm{d}}$ Department of Statistics, Southern Methodist University, Dallas; and Departments of ${ }^{\mathrm{e}}$ Cardiothoracic Surgery and ${ }^{\mathrm{f}} \mathrm{Cardiology}$, Baylor Heart and Vascular Institute, Baylor University Medical Center, Dallas, Tex.

This work was funded in part by the Bradley Family Endowment to the Baylor Health Care System Foundation and The Baylor Health Care System Cardiovascular Research Committee (Dallas, Tex). expand access to $\mathrm{CABG}$ to patients in developing countries in which cardiopulmonary bypass was either not available or cost prohibitive, ${ }^{2}$ now accounts for greater

Received for publication Nov 21, 2016; revisions received July 24, 2017; accepted for publication Aug 9, 2017; available ahead of print Sept 26, 2017.

Address for reprints: Giovanni Filardo, $\mathrm{PhD}, \mathrm{MPH}$, Office of the Chief Quality Officer, Baylor Scott \& White Health, 8080 North Central Expressway, Suite 900, Dal-

las, TX 75206 (E-mail: giovanfi@baylorhealth.edu). $0022-5223 / \$ 36.00$

Copyright (C) 2017 by The American Association for Thoracic Surgery http://dx.doi.org/10.1016/j.jtcvs.2017.08.026 

Abbreviations and Acronyms
$\mathrm{CABG}=$ coronary artery bypass graft
$\mathrm{RCT}=$ randomized controlled trial
STS $=$ Society of Thoracic Surgeons

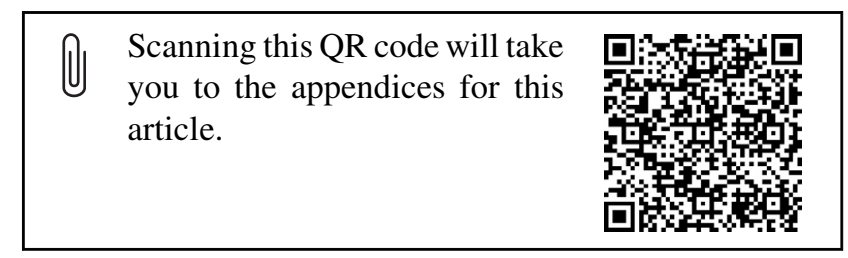

than $60 \%$ of CABG procedures performed in Asia and $15 \%$ to $20 \%$ of those performed in Western nations. ${ }^{2-4}$ Widespread interest in this technique has been fueled by the possibility that avoiding cardiopulmonary bypass can reduce the adverse complications seen after conventional CABG. Possible disadvantages, however, include greater technical complexity and reduced graft patency and completeness of revascularization. ${ }^{5-7}$

Many studies-observational and randomized controlled trials (RCTs) - have compared outcomes after off- and onpump CABG, with results ranging from equivalent outcomes to favoring off-pump or on-pump CABG. This has led to meta-analyses attempting to consolidate the evidencemore than 20 looking at various outcomes and subgroups of studies have been published since 2003. However, those examining mortality in the general population of patients undergoing CABG have focused on short- or long-term ${ }^{8-10}$ results only and/or, with few exceptions, ${ }^{8,9,11,12}$ exclusively on RCTs. The wealth of data from rigorous observational studies (covering $>1.1$ million patients to date) frequently is ignored. RCTs and observational studies each have their own strengths and weaknesses. Although RCTs remain the gold standard for establishing causation between a therapy and outcomes, they are best suited to evaluating straightforward, discrete interventions in controlled environments, and study findings frequently do not translate into benefits in real-world settings, leaving uncertainty about how therapies should be best applied within the larger environment of the health care delivery system. ${ }^{13}$

As a result, evidence from traditional RCTs generally needs to be supplemented by evidence from effectiveness studies to usefully inform clinical practice. ${ }^{13}$ Here, we provide a comprehensive picture regarding the outcomes associated with off- versus on-pump CABG by assessing both the efficacy (RCTs) and the effectiveness (observational studies) ${ }^{14}$ of these techniques in terms of mortality and survival. Recognizing that RCT and observational data provide valuable insight into particular aspects of questions about efficacy and effectiveness when examined separately, we report results for the subgroups of RCTs and observational studies in isolation. In addition, by using the risk-adjusted results from methodologically rigorous observational studies, we combined the results of all the included studies to provide an overall estimate that summarizes both the experimental and real-world evidence comparing off- versus on-pump CABG.

\section{METHODS \\ Search Strategy}

We conducted a systematic search in PubMed (which accesses MEDLINE, PreMEDLINE, HealthSTAR, the Cochrane Database of Systematic Reviews, publisher-supplied citations, and other related databases) using the search string "Coronary Artery Bypass" [Mesh] AND ("Coronary Artery Bypass, Off-Pump” [Mesh] OR off-pump) AND on-pump AND mortality, and applying the Article type (Clinical Trial, Comparative Study, Meta-Analysis, Review, Systematic Reviews), Species (Humans), and Language (English) filters. Bibliographies of meta-analyses and review articles were reviewed for relevant articles, and the search was last run on June 30, 2015.

\section{Study Inclusion and Exclusion Criteria}

Our study focused on the efficacy and effectiveness of on- versus offpump CABG techniques in the general elective CABG patient population (rather than in specific subgroups, such as CABG patients with a particular comorbidity), with the goal of producing results that would be highly generalizable to the real world and that provide a more comprehensive picture regarding the outcomes associated with these techniques. We therefore included all studies (RCTs and observational study in which the risk-adjustment accounted, at minimum, for the relevant risk factors for mortality recognized by the Society of Thoracic Surgeons $[\mathrm{STS}]^{15}$ ) comparing short-term (operative, in-hospital, or 30-days) or long-term ( $\geq 1$ year) all-cause mortality for patients undergoing on-pump versus off-pump isolated CABG. We excluded articles if they (1) reported results only of a literature review or metaanalysis; (2) were restricted to patients with a specific demographic characteristic (eg, age $<50$ years), cardiac condition (eg, ejection fraction $\leq 35 \%$ ), comorbidity (eg, diabetes), or undergoing a specific type of $\mathrm{CABG}$ procedure (eg, redo procedures) or CABG with a simultaneous or synchronous additional procedure; (3) reported results of an observational study in which the mortality/survival comparison for on-pump versus off-pump CABG was not risk adjusted to account, at minimum, for the relevant risk factors for mortality recognized by the STS; or (4) used the same study cohort as another included study and reported mortality at the same time points.

\section{Data Abstraction and Management}

Abstracts and full text of the articles retrieved through the systematic search were reviewed independently by at least 2 investigators, with D.S. and G.F. acting as the final arbiters. For included studies, 2 investigators independently collected information on the participants (cohort size and number of subjects in each study group), the type of study (RCT or observational study) and the number of all-cause deaths (in the case of observational studies, the adjusted estimate of the number of all-cause deaths) at each time point reported. There were no missing data, and, while levels of disagreement varied between investigator pairings, they were generally low $(<2 \%)$ and easily reconciled through discussion. Reconciled data were entered into RevMan 5.2. ${ }^{16}$ 


\section{Assessment of Risk of Bias}

The included studies were assessed for risk of bias using the tool described in the Cochrane handbook ${ }^{16}$ for systematic reviews of interventions, adapted, for the observational studies, for application to nonrandomized study designs. Each article was evaluated independently by 2 investigators, with D.S. and G.F. acting as the final arbiters, who judged them to have low, high, or unclear risk of bias in each of the domains shown in Figure 2. Funnel plots were generated to assess publication bias.

\section{Statistical Analysis and Data Synthesis \\ Summary of measures. Odds ratios (short-term mortality: opera- tive/in-hospital/30-day), relative risk (long-term mortality: 1, 3, 5, and 10 years), differences in probability of mortality, and $95 \%$ confidence in- tervals based on Mantel-Haenszel $\chi^{2}$ were estimated to compare mortality after off-pump versus on-pump CABG. Crude deaths were used to estimate the measure of associations described above in RCTs-expected deaths based on the adjusted point estimate were used for each observational study. Expected deaths were used for observational studies so that patient case-mix was appropriately accounted for in the analysis. \\ Given the large number of studies considered, and, more importantly, the large cohort sizes of some of these studies, the summary estimates were calculated with a fixed effect meta-analysis approach. ${ }^{17}$ A sensitivity analysis that used a random effects model also was conducted.}

Subgroup analysis. Estimates and forest plots were presented overall and for the subgroups of RCTs and risk-adjusted observational studies. By limiting the included observational studies to those adjusted for, at minimum, the relevant STS risk factors, and by using the adjusted odds and risk ratios they reported to estimate the number of deaths in the on- versus offpump groups for this meta-analysis, the analysis for the observational studies was adjusted for a comprehensive array of clinical and nonclinical risk factors to account for patient case-mix.

Heterogeneity. Tests of heterogeneity were conducted. Each analysis that yielded a significant (alpha $=0.05$ ) heterogeneity test result was repeated twice, first excluding the studies with the largest, then those with the smallest, cohort sizes until the heterogeneity test result was nonsignificant-estimates were then compared with those obtained in presence of heterogeneity.

Sensitivity analyses. For all study time-points, irrespective of the heterogeneity test results, sensitivity analyses were conducted. We excluded the largest and then the smallest studies, and compared the estimates computed with the ones obtained without excluding large or small studies. We then assessed possible bias from our study exclusion criteria by repeating our analyses including those studies we excluded based on their study populations being limited to patients with a specific demographic (sex, or age $\geq 75$ years) or clinical characteristic (eg, patients with diabetes, or patients on dialysis), and compared the study estimates. We also repeated the analyses including those studies excluded for having inadequate risk adjustment.

All the analyses were conducted with The Cochrane Collaboration Review Manager 5.2 software. Because only previously published data were collected for and used in this study, institutional review board approval was not sought.

\section{RESULTS}

\section{Included Studies}

Figure 1 shows the inclusion/exclusion flowchart for studies considered for this meta-analysis; characteristics of the 73 included studies are summarized in Table E1, and the excluded studies are listed in the Online Data Supplement.

\section{Risk of Bias}

Overall, the risk of bias in the included studies was low (Figure 2). Likewise, the funnel plots (not shown) did not show any asymmetry indicating concerns about publication bias.

\section{Synthesis of Results}

Short term mortality was investigated in $\sim 1.2$ million patients and long-term mortality ( $\geq 1$ year) in $\sim 91,000$ patients. Table 1 shows odds ratios, relative risks, and 95\% confidence intervals at each time point.

Figures 3 and 4 show details and Forest plots for the fixed-effect short-term mortality and 5- and 10-year survival analyses respectively. Results are reported for RCTs and adjusted observational studies, both separately and combined.

\section{Heterogeneity and Sensitivity Analyses}

The sensitivity analyses confirmed our results and heterogeneity did not affect study findings. This included the sensitivity analyses conducted to determine whether the exclusion of studies limited to patients with a specific demographic or clinical characteristic biased our results.

\section{DISCUSSION}

In this meta-analysis, we assessed both the efficacy and the effectiveness of the 2 operative techniques in 73 studies comparing mortality in $\sim 1.2$ million patients undergoing on-pump versus off-pump isolated CABG procedures. Overall and in the subgroup of risk-adjusted observational studies, we observed a significant $43 \%$ reduction in risk of short-term mortality associated with off-pump CABG; however, no similar advantage was observed in the subgroup of RCTs. Looking at the long-term results, we found that, overall, any early advantage for off-pump was lost by 1 year and became a significant disadvantage by 5 years. The same held true for the subgroup of risk-adjusted observational studies, with the disadvantage being sustained at 10 years, a period over which patients undergoing offpump CABG had a statistically significant $15 \%$ greater risk of mortality. In the subgroup of RCTs reporting survival at 5 years, there was no significant difference (the 2 larger RCTs showed a nonsignificant benefit with on-pump, whereas the 1 smaller RCT showed a significant benefit with off-pump); no RCT data were available at 10 years. Taken together, the results from the combined analysis, summarizing both experimental and real-world setting data, and from the adjusted observational studies alone suggest that any perioperative advantage the off-pump technique offers likely comes at the price of poorer long-term outcomes.

One possible explanation for this "price" is that lesscomplete revascularization is achieved with off-pump CABG. Poorer quality of anastomoses and inadequacy of revascularization have been raised as concerns. ${ }^{3}$ Although there is some evidence that these problems are less prevalent in more recent studies, ${ }^{7}$ other results show them to be 


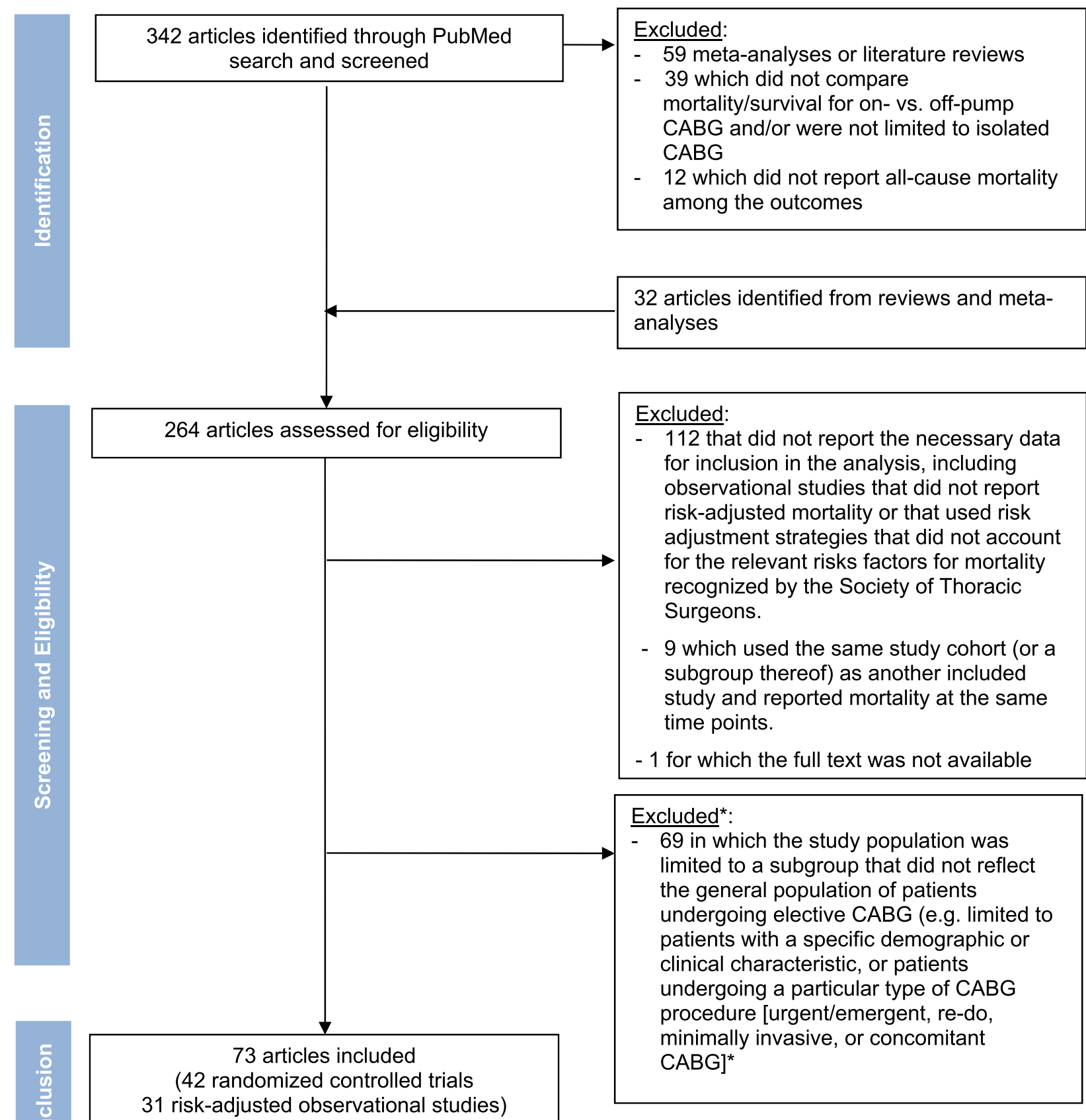

FIGURE 1. Study inclusion and exclusion flowchart. *Sensitivity analyses that included the studies excluded because they were limited to subgroups based on particular demographic or clinical characteristics (eg, patients age $\geq 75$ years, or patients with diabetes) or because they used risk adjustment strategies that did not account for the relevant risks factors for mortality recognized by the Society of Thoracic Surgeons were conducted to ensure these exclusions did not bias our results. The sensitivity analyses extended to these excluded studies confirmed the study results. $C A B G$, Coronary artery bypass graft.

ongoing $^{6}$ and the associated loss of survival substantial $(37 \%) .{ }^{18}$ Unfortunately, few of the studies in our metaanalysis provided information on graft patency and completeness of revascularization, so we could not include these factors.

Another possible explanation for the long-term poorer outcomes with off-pump CABG is selection bias inherent in the observational studies-including immeasurable subjective bias that may be inherent in surgeons' decision-making that cannot be accounted for through risk-adjustment. However, the fact that the subgroup analyses of the risk-adjusted observational studies suggest both significantly lower operative/in-hospital/30-day mortality and significantly lower 5 and 10-year survival 


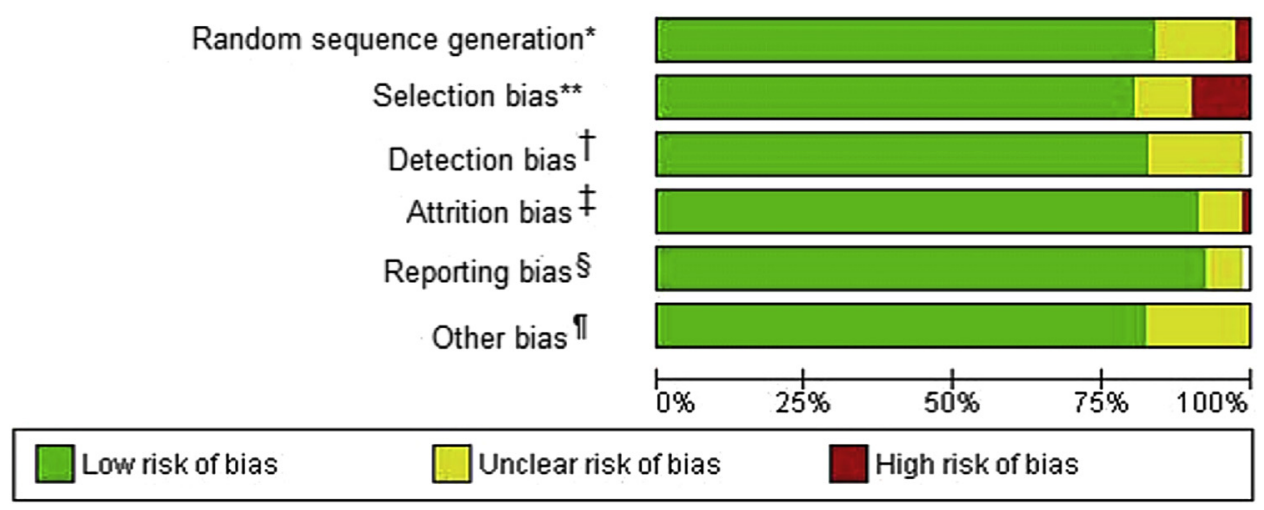

FIGURE 2. Risk of bias graph. *Applicable only to randomized controlled trials ( 42 of the 73 included articles). **For randomized controlled trials, we looked for allocation bias and whether or not an intention-to-treat analysis was used; for observational studies, we determined the risk of selection bias based on whether the same inclusion/exclusion criteria applied to the on- and off-pump groups, and a combination of whether the reported characteristics of the 2 groups showed imbalance and the adequacy of the risk adjustment method applied. †Whether different methods were used to determine mortality/survival between the 2 groups. $\ddagger$ Studies were considered to have a high risk of attrition bias if $>20 \%$ of patients were lost to follow-up. $\S$ Studies were considered to have a high risk of reporting bias if there was evidence that prespecified outcomes were not reported. $\uparrow$ Other sources of bias included any limitations on the study population that did not trigger our exclusion criteria (eg, limited to age $>65$ years, or to "low risk" patients), and whether patients converted from offpump to on-pump during surgery were analyzed as part of the off-pump group (low risk) or on-pump group (high risk) or excluded (unclear risk).

associated with off-pump CABG makes the selection bias hypothesis unlikely.

Our short-term results are consistent with 3 previous meta-analyses: One that was limited to RCTs but observed a similar reduction in short-term mortality $(18 \%$ lower odds of death) with off-pump CABG, and 2 which considered observational studies, and found much greater reductions in operative mortality $(>30 \%))^{11,12,19}$ However, 3 other recent meta-analyses (all limited to RCTs), including the 2012 Cochrane Systematic Review, showed no significant difference in short-term mortality. ${ }^{10,20,21}$ Our long-term results are consistent with the largest and most recent meta-analyses that examined mortality at time points greater than 30 days post-CABG: 2 were limited to RCTs and report a substantially greater increase in the risk of death associated with off-pump CABG $(\sim 35 \%)^{21,22}$ than the $10 \%$ and $14 \%$ increases we observed at 5 and 10 years; the remaining 2 included both RCTs and observational studies-one found no significant difference at 1 to 5 years, but a $6 \%$ increased risk of death at $>5$ years, ${ }^{8}$ the other reported a statistically significant $7 \%$ increase in long-term all-cause mortality with off-pump CABG. ${ }^{9}$

Few results of RCTs were available for several of the time points past 5 years postsurgery. However, the 8 studies reporting 5-year results and the 5 studies reporting 10-year results provided $\sim 60,000$ patients for each of these time points, bolstering the strength of the conclusions we can draw while waiting for the long-term results of the 2 large $\mathrm{RCTs}^{23,24}$ that offer the best opportunity for detecting differences in survival.

Our results have important implications regarding the use of off-pump versus on-pump CABG. They strengthen the conclusions of recent studies ${ }^{9,21,22}$ that off-pump CABG offers patients poorer long-term survival. Being drawn from a set of high-quality studies, not limited either in the timeframe for which outcomes were considered nor to the unique context of RCTs, our results provide the most

TABLE 1. Odds ratios, relative risks, and differences in probability of mortality (with $95 \%$ CIs) after off- vs on-pump CABG, by time

\begin{tabular}{|c|c|c|c|c|c|c|c|c|}
\hline \multirow{3}{*}{$\begin{array}{c}\text { Mortality } \\
\text { Time } \\
\text { point }\end{array}$} & \multirow{3}{*}{$\begin{array}{c}\text { Number } \\
\text { of } \\
\text { studies }\end{array}$} & \multirow[b]{3}{*}{ RCT } & \multirow[b]{3}{*}{ Observational } & \multirow{3}{*}{$\begin{array}{c}\text { Total number } \\
\text { of study } \\
\text { subjects }\end{array}$} & \multicolumn{4}{|c|}{ Off-pump vs on-pump CABG } \\
\hline & & & & & \multicolumn{2}{|c|}{ Fixed effect model } & \multicolumn{2}{|c|}{ Random effects model } \\
\hline & & & & & $\begin{array}{c}\text { Relative } \\
\text { risk }(95 \% \mathbf{C I})\end{array}$ & $\begin{array}{l}\text { Difference in probability } \\
\text { of mortality }(95 \% \mathrm{CI})\end{array}$ & $\begin{array}{c}\text { Relative } \\
\text { risk }(95 \% \text { CI })\end{array}$ & $\begin{array}{c}\text { Difference in probability } \\
\text { of mortality }(95 \% \mathrm{CI})\end{array}$ \\
\hline Short term & 62 & 36 & 26 & $1,216,924$ & $0.81(0.78,0.83)^{*}$ & $-44.8(-45.4,-43.8)$ & $0.72(0.66,0.79)^{*}$ & $-41.9(-44.1,-39.8)$ \\
\hline $1 \mathrm{y}$ & 14 & 9 & 5 & 61,064 & $0.96(0.89,1.04)$ & $4.2(4.0,12.4)$ & $0.96(0.89,1.04)$ & $4.2(4.0,12.4)$ \\
\hline $3 y$ & 5 & 2 & 3 & 50,186 & $1.05(0.99,1.12)$ & $5.0(-1.0,12.0)$ & $1.07(0.95,1.20)$ & $7.0(-5.3,20.0)$ \\
\hline $5 y$ & 8 & 3 & 5 & 60,495 & $1.10(1.05,1.15)$ & $10.0(5.0,15.0)$ & $1.11(1.03,1.20)$ & $11.0(3.0,20.0)$ \\
\hline $10 \mathrm{y}$ & 5 & 0 & 5 & 59,125 & $1.14(1.11,1.17)$ & $14.0(11.0,17.0)$ & $1.12(1.00,1.25)$ & $12.0(0.0,25.0)$ \\
\hline
\end{tabular}

$C A B G$, Coronary artery bypass graft; $R C T$, randomized controlled trial; $C I$, confidence interval. *Odds ratio $(95 \% \mathrm{CI})$. 


\section{Operative/in-hospital/30-day mortality}

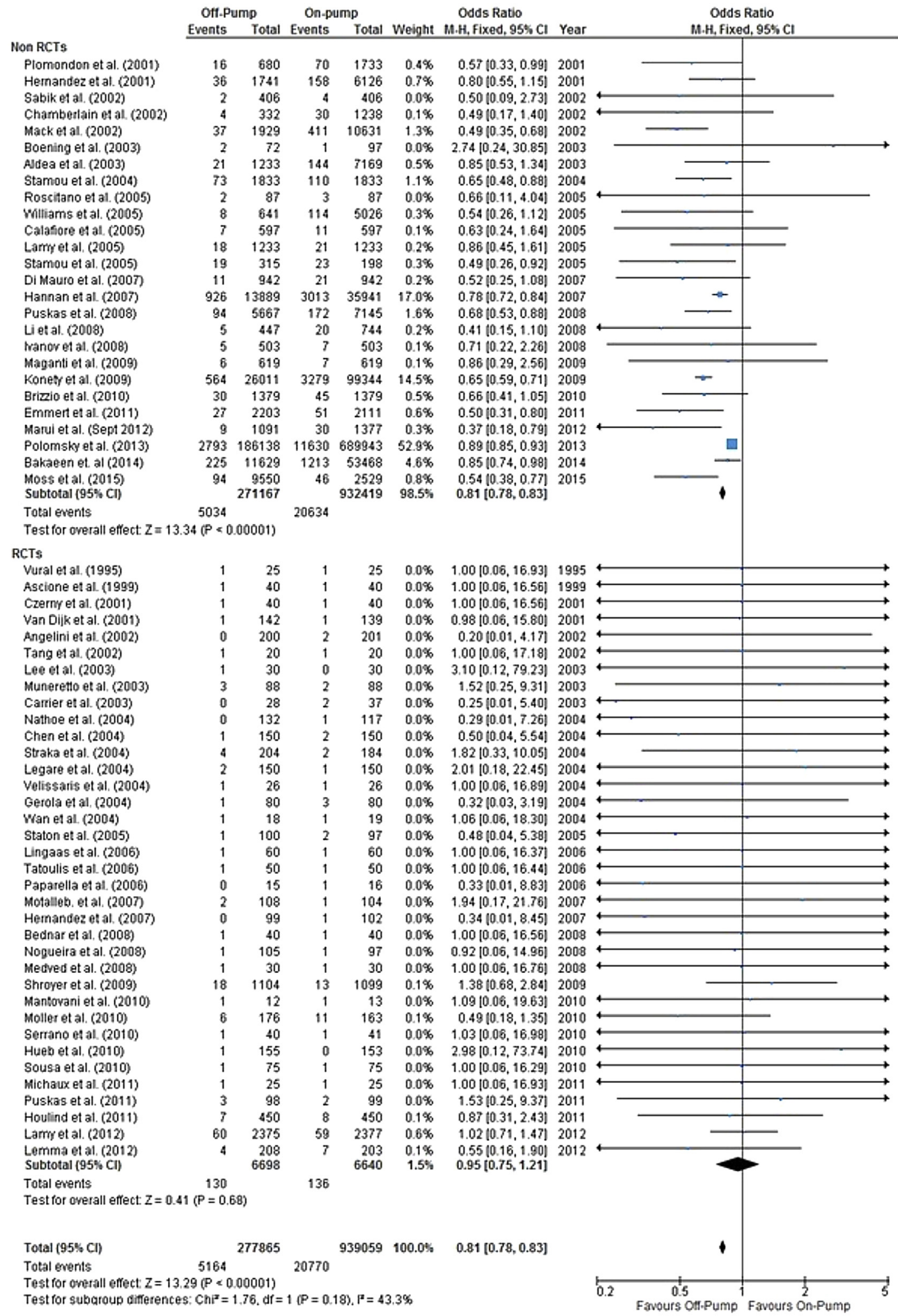

FIGURE 3. Forest plot summarizing meta-analysis results for short term mortality (operative/in-hospital/30-day). Estimates for studies reporting zero events in both study arms were computed by setting 1 event per arm. $M-H$, Mantel-Haenszel; $C I$, confidence interval; $R C T$, randomized controlled trial. 

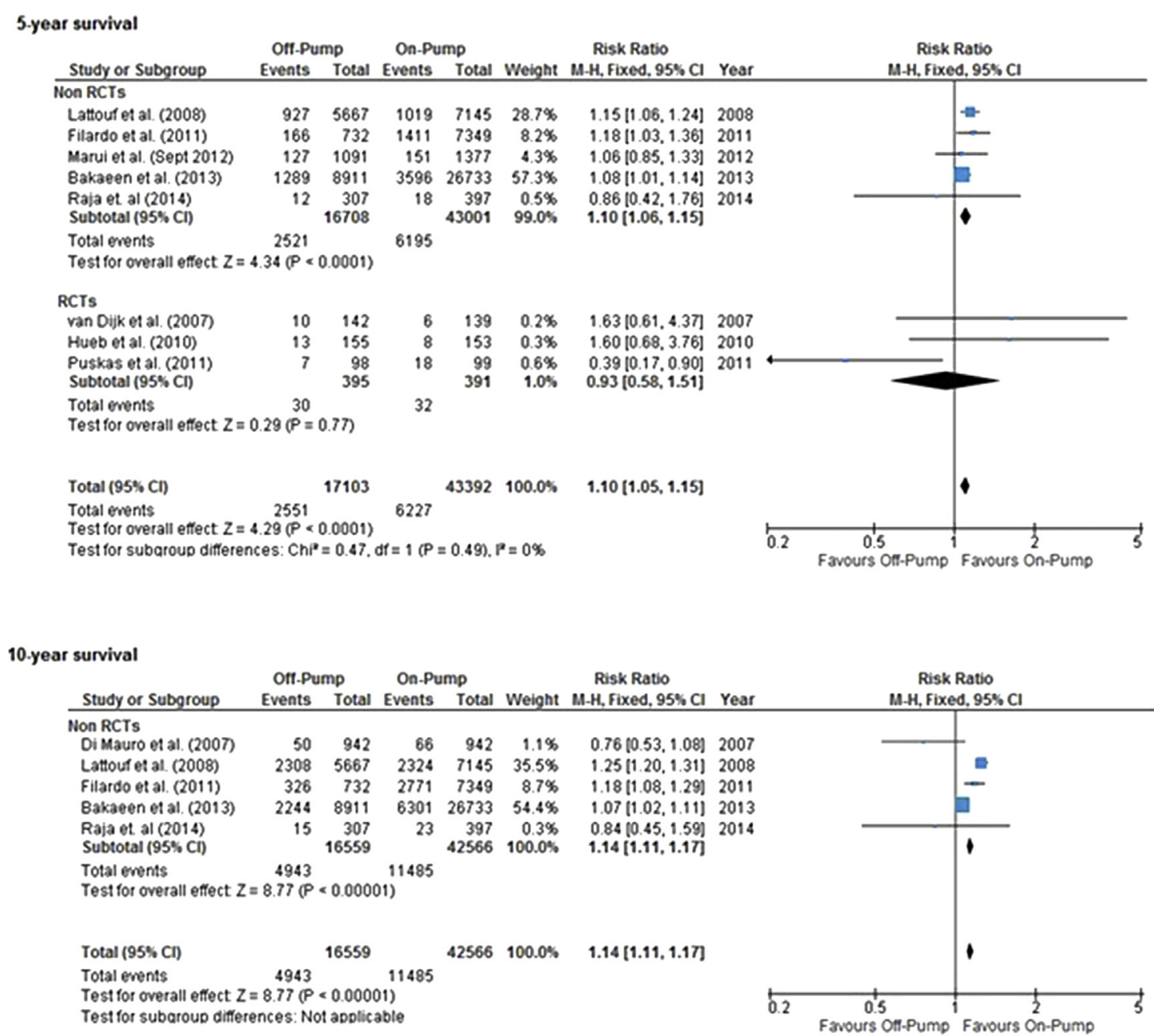

FIGURE 4. Forest plots summarizing meta-analysis results for 5- and 10 -year survival. $M$ - $H$, Mantel-Haenszel; $C I$, confidence interval; $R C T$, randomized controlled trial.

comprehensive picture of the evidence that cardiothoracic surgeons should be considering when advising patients on the choice between on- and off-pump CABG.

Lastly, our results are particularly valuable because they provide the full picture regarding the efficacy (experimental data) and effectiveness (real-world data) of off- and on-pump CABG in terms of mortality and survival by presenting and summarizing, combined and separately, RCT and observational study data. Although the RCT-only data provide insight into how the techniques compare in the regimented and idealized conditions of clinical trials (including experienced clinical teams and surgeons who have specialized in a particular technique, as well as resources for protocol-dictated patient follow-up), data from the rigorously adjusted observational studies allow for the assessment of how the techniques compare in the real-world. These data are critical because the evidence derived from RCTs can be difficult to translate into the real-world setting, where the clinical experience and resources available, as well as the characteristics of the patient population, may differ greatly from the protocol-driven RCT framework. The differences observed in our results between the RCTonly and the observational studies-only analyses demonstrates the well-recognized complexity of translating RCT results to the broader, real-world setting and patient population.

The majority of CABG procedures in Western nations are still performed on-pump, but there has been substantial interest in the off-pump technique, with some institutions reporting its use in $90 \%$ of cases. ${ }^{25}$ Our results show that, before this trend gains any further ground, we must look critically at the evidence for clinical benefit with offpump versus on-pump CABG to avoid decisions that may ultimately deprive patients of the long-term benefits they seek through CABG.

\section{Conflicts of Interest Statement}

Authors have nothing to disclose with regard to commercial support. 


\section{References}

1. Athanasiou T, Saso S, Rao C, Vecht J, Grapsa J, Dunning J, et al. Radial artery versus saphenous vein conduits for coronary artery bypass surgery: forty years of competition-which conduit offers better patency? A systematic review and meta-analysis. Eur J Cardiothorac Surg. 2011;40:208-20.

2. Taggart DP, Altman DG. Off-pump vs. on-pump CABG: are we any closer to a resolution? Eur Heart J. 2012;33:1181-3.

3. Huffmyer J, Raphael J. The current status of off-pump coronary bypass surgery. Curr Opin Anaesthesiol. 2011;24:64-9.

4. Patel NN, Angelini GD. Off-pump coronary artery bypass grafting: for the many or the few? J Thorac Cardiovasc Surg. 2010;140:951-3.e1.

5. Polomsky M, He X, O'Brien SM, Puskas JD. Outcomes of off-pump versus onpump coronary artery bypass grafting: Impact of preoperative risk. J Thorac Cardiovasc Surg. 2013;145:1193-8.

6. Hattler B, Messenger JC, Shroyer AL, Collins JF, Haugen SJ, Garcia JA, et al. Off-Pump coronary artery bypass surgery is associated with worse arterial and saphenous vein graft patency and less effective revascularization: results from the Veterans Affairs Randomized On/Off Bypass (ROOBY) trial. Circulation. 2012; $125: 2827-35$

7. Hijazi EM. Is it time to adopt beating-heart coronary artery bypass grafting? A review of literature. Rev Bras Cir Cardiovasc. 2010;25:393-402.

8. Chaudhry UA, Harling L, Rao C, Ashrafian H, Ibrahim M, Kokotsakis J, et al. Off-pump versus on-pump coronary revascularization: meta-analysis of midand long-term outcomes. Ann Thorac Surg. 2014;98:563-72.

9. Takagi H, Umemoto T. All-Literature Investigation of Cardiovascular Evidence G. Worse long-term survival after off-pump than on-pump coronary artery bypass grafting. J Thorac Cardiovasc Surg. 2014;148:1820-9.

10. Deppe AC, Arbash W, Kuhn EW, Slottosch I, Scherner M, Liakopoulos OJ, et al. Current evidence of coronary artery bypass grafting off-pump versus on-pump: a systematic review with meta-analysis of over 16900 patients investigated in randomized controlled trials dagger. Eur J Cardiothorac Surg. 2016;49:1031-41; discussion 1041.

11. Kuss O, von Salviati B, Borgermann J. Off-pump versus on-pump coronary artery bypass grafting: a systematic review and meta-analysis of propensity score analyses. J Thorac Cardiovasc Surg. 2010;140:829-35. 35.e1-13.

12. Reston JT, Tregear SJ, Turkelson CM. Meta-analysis of short-term and mid-term outcomes following off-pump coronary artery bypass grafting. Ann Thorac Surg. 2003;76:1510-5.

13. Nallamothu BK, Hayward RA, Bates ER. Beyond the randomized clinical trial: the role of effectiveness studies in evaluating cardiovascular therapies. Circulation. 2008;118:1294-303.

14. Higgins JPT, Green S, eds. Cochrane Handbook for Systematic Reviews of Interventions Version 5.1.0 [updated March 2011]. The Cochrane Collaboration; 2011. Available at: http://handbook-5-1.cochrane.org/. Accessed September 19, 2017.

15. Shahian DM, O'Brien SM, Filardo G, Ferraris VA, Haan CK, Rich JB, et al. The Society of Thoracic Surgeons 2008 cardiac surgery risk models: part 1 -coronary artery bypass grafting surgery. Ann Thorac Surg. 2009;88(1 suppl):S2-22.

16. Review Manager (RevMan) [Computer program]. Version 5.2. Copenhagen: The Nordic Cochrane Centre, The Cochrane Collaboration; 2012.

17. Higgins JP, Thompson SG, Deeks JJ, Altman DG. Measuring inconsistency in meta-analyses. BMJ. 2003;327:557-60.

18. Takagi H, Watanabe T, Mizuno Y, Kawai N, Umemoto T, Group A. A metaanalysis of adjusted risk estimates for survival from observational studies of complete versus incomplete revascularization in patients with multivessel disease undergoing coronary artery bypass grafting. Interact Cardiovasc Thorac Surg. 2014;18:679-82

19. Godinho AS, Alves AS, Pereira AJ, Pereira TS. On-pump versus off-pump coronary-artery bypass surgery: a meta-analysis. Arq Bras Cardiol. 2012; 98:87-94.

20. Afilalo J, Rasti M, Ohayon SM, Shimony A, Eisenberg MJ. Off-pump vs. on pump coronary artery bypass surgery: an updated meta-analysis and metaregression of randomized trials. Eur Heart J. 2012;33:1257-67.

21. Moller CH, Penninga L, Wetterslev J, Steinbruchel DA, Gluud C. Off-pump versus on-pump coronary artery bypass grafting for ischaemic heart disease. Cochrane Database Syst Rev 2012;3:CD007224.

22. Takagi H, Yamamoto H, Iwata K, Goto SN, Umemoto T. Ask not which can impair early morbidity—ask which can improve late survival: a meta-analysis of randomized trials of off-pump versus on-pump coronary artery bypass. Int $J$ Cardiol. 2012;158:435-8

23. Lamy A, Devereaux PJ, Prabhakaran D, Taggart DP, Hu S, Paolasso E, et al. Offpump or on-pump coronary-artery bypass grafting at 30 days. $N$ Engl J Med 2012;366:1489-97.

24. Shroyer AL, Grover FL, Hattler B, Collins JF, McDonald GO, Kozora E, et al On-pump versus off-pump coronary-artery bypass surgery. $N$ Engl $\mathrm{J}$ Med. 2009;361:1827-37.

25. Polomsky M, Puskas JD. Off-pump coronary artery bypass grafting-the current state. Circ J. 2012;76:784-90.

Key Words: coronary artery bypass graft, mortality, metaanalysis, off-pump surgery 


\begin{tabular}{|c|c|c|c|c|}
\hline & Study type & Cohort size & $\begin{array}{l}\text { Period during which } \\
\text { surgeries were } \\
\text { performed }\end{array}$ & $\begin{array}{c}\text { Time points at } \\
\text { which mortality } \\
\text { results were } \\
\text { reported/included } \\
\text { in the meta-analysis }\end{array}$ \\
\hline \multicolumn{5}{|l|}{ RCTs } \\
\hline Vural and colleagues $(1995)^{\mathrm{E} 1}$ & RCT & 25 off-pump, 25 on-pump & Not reported & Short term \\
\hline Ascione and colleagues (1999) $)^{\mathrm{E} 2}$ & RCT & 40 off-pump, 40 on-pump & Not reported & Short term \\
\hline Czerny and colleagues (2001) $)^{\mathrm{E} 3}$ & RCT & 40 off-pump, 40 on-pump & Not reported & Short term \\
\hline van Dijk and colleagues $(2001)^{\mathrm{E} 4}$ & RCT & 142 off-pump, 139 on-pump & $3 / 1998$ to $8 / 2000$ & Short term \\
\hline Angelini and colleagues $(2002)^{\mathrm{E} 5}$ & $\begin{array}{l}\text { Pooled analysis } \\
\text { of } 2 \text { RCTs }\end{array}$ & 200 off-pump, 201 on-pump & $\begin{array}{l}3 / 1997 \text { to } 8 / 1998 \\
9 / 1998 \text { to } 11 / 1999\end{array}$ & Short term, 2 y \\
\hline Tang and colleagues $(2002)^{\mathrm{E} 6}$ & RCT & 20 off-pump, 20 on-pump & Not reported & Short term \\
\hline Carrier and colleagues $(2003)^{\mathrm{E} 7}$ & RCT & 28 off-pump, 37 on-pump & $10 / 2001$ to $9 / 2002$ & Short term \\
\hline Lee and colleagues $(2003)^{\mathrm{E} 8}$ & RCT & 30 off-pump, 30 on-pump & $4 / 1999$ to $9 / 2001$ & Short term \\
\hline Muneretto and colleagues $(2003)^{\mathrm{E} 9}$ & RCT & 88 off-pump, 88 on-pump & $1 / 2000$ to $1 / 2002$ & Short term, $1 \mathrm{y}$ \\
\hline Nathoe and colleagues $(2003)^{\mathrm{E} 10}$ & RCT & 142 off-pump, 139 on-pump & $3 / 1998$ to $8 / 2000$ & $1 \mathrm{y}$ \\
\hline Chen et al $(2004)^{\mathrm{E} 11}$ & RCT & 150 off-pump, 150 on-pump & $6 / 2001$ to $4 / 2003$ & Short term \\
\hline Gerola and colleagues $(2004)^{\mathrm{E} 12}$ & RCT & 80 off-pump, 80 on-pump & Not reported & Short term \\
\hline Légaré and colleagues $(2004)^{\mathrm{E} 13}$ & RCT & 150 off-pump, 150 on-pump & $8 / 1999$ to $3 / 2003$ & Short term \\
\hline Nathoe and colleagues $(2004)^{\mathrm{E} 14}$ & RCT & 132 off-pump, 117 on-pump & $3 / 1998$ to $8 / 2000$ & Short term, $1 \mathrm{y}$ \\
\hline Straka and colleagues $(2004)^{\mathrm{E} 15}$ & $\mathrm{RCT}$ & 204 off-pump, 184 on-pump & $5 / 2000$ to $6 / 2002$ & Short term \\
\hline Velissaris and colleagues $(2004)^{\mathrm{E} 16}$ & $\mathrm{RCT}$ & 26 off-pump, 26 on-pump & Not reported & Short term \\
\hline Wan and colleagues $(2004)^{\mathrm{E} 17}$ & $\mathrm{RCT}$ & 18 off-pump, 19 on-pump & Not reported & Short term \\
\hline Staton and colleagues $(2005)^{\mathrm{E} 18}$ & RCT & 100 off-pump, 97 on-pump & Not reported & Short term \\
\hline Lingaas and colleagues $(2006)^{\mathrm{E} 19}$ & $\mathrm{RCT}$ & 60 off-pump, 60 on-pump & Not reported & Short term \\
\hline Paparella and colleagues $(2006)^{\mathrm{E} 20}$ & RCT & 15 off-pump, 16 on-pump & Not reported & Short term \\
\hline Tatoulis and colleagues $(2006)^{\mathrm{E} 21}$ & $\mathrm{RCT}$ & 50 off-pump, 50 on-pump & Not reported & Short term \\
\hline Hernandez and colleagues $(2007)^{\mathrm{E} 22}$ & RCT & 99 off-pump, 102 on-pump & $1 / 2001$ to $1 / 2004$ & Short term \\
\hline Karolak and colleagues $(2007)^{\mathrm{E} 23}$ & RCT & 150 off-pump, 150 on-pump & $8 / 1999$ to $3 / 2003$ & $4 y$ \\
\hline Motallebzadeh and colleagues $(2007)^{\mathrm{E} 24}$ & RCT & 108 off-pump, 104 on-pump & $8 / 2002$ to $3 / 2004$ & Short term \\
\hline van Dijk et al (2007) & $\mathrm{RCT}$ & 142 off-pump, 139 on-pump & 1998 to 2000 & $5 \mathrm{y}$ \\
\hline Bednar and colleagues $(2008)^{\mathrm{E} 26}$ & RCT & 40 off-pump, 40 on-pump & $5 / 2005$ to $12 / 2006$ & Short term \\
\hline Medved and colleagues $(2008)^{\mathrm{E} 27}$ & $\mathrm{RCT}$ & 30 off-pump, 30 on-pump & $1 / 15 / 2006$ to $6 / 30 / 2007$ & Short term \\
\hline Nogueira and colleagues $(2008)^{\mathrm{E} 28}$ & $\mathrm{RCT}$ & 105 off-pump, 97 on-pump & $1 / 2002$ to $12 / 2006$ & Short term \\
\hline Angelini and colleagues (2009) $)^{\mathrm{E} 29}$ & $\mathrm{RCT}$ & 200 off-pump, 201 on-pump & $\begin{array}{l}3 / 1997 \text { to } 8 / 1998 \\
9 / 1998 \text { to } 11 / 1999\end{array}$ & $6 y$ \\
\hline Shroyer and colleagues (2009) ${ }^{\mathrm{E} 30}$ & RCT & 1104 off-pump, 1099 on-pump & $2 / 2002$ to $5 / 2008$ & Short term, $1 \mathrm{y}$ \\
\hline Hueb and colleagues $(2010)^{\mathrm{E} 31}$ & RCT & 155 off-pump, 153 on-pump & $3 / 2001$ to $3 / 2006$ & Short term, $5 \mathrm{y}$ \\
\hline Mantovani and colleagues $(2010)^{\mathrm{E} 32}$ & RCT & 12 off-pump, 13 on-pump & Not reported & Short term \\
\hline Møller and colleagues (2010) ${ }^{\mathrm{E} 33}$ & RCT & 176 off-pump, 163 on-pump & $4 / 2002$ to $3 / 2006$ & Short term \\
\hline Serrano and colleagues $(2010)^{\mathrm{E} 34}$ & RCT & 40 off-pump, 41 on-pump & $3 / 2001$ to $3 / 2006$ & Short term, 1 y \\
\hline Sousa Uva and colleagues $(2010)^{\mathrm{E} 35}$ & RCT & 75 off-pump, 75 on-pump & $4 / 2005$ to $7 / 2007$ & Short term, 1 y \\
\hline Michaux and colleagues $(2011)^{\mathrm{E} 36}$ & RCT & 25 off-pump, 25 on-pump & Not reported & $\begin{array}{c}\text { Short term, } 1 \mathrm{y}, \\
2 \mathrm{y}\end{array}$ \\
\hline Møller and colleagues $(2011)^{\mathrm{E} 37}$ & $\mathrm{RCT}$ & 176 off-pump, 163 on-pump & $4 / 2002$ to $3 / 2006$ & $3 y$ \\
\hline Puskas and colleagues (2011) $)^{\mathrm{E} 38}$ & $\mathrm{RCT}$ & 98 off-pump, 99 on-pump & $3 / 2000$ to $8 / 2001$ & 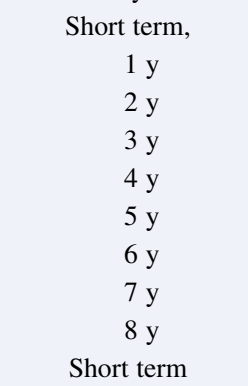 \\
\hline
\end{tabular}




\begin{tabular}{|c|c|c|c|c|}
\hline & Study type & Cohort size & $\begin{array}{c}\text { Period during which } \\
\text { surgeries were } \\
\text { performed }\end{array}$ & $\begin{array}{c}\text { Time points at } \\
\text { which mortality } \\
\text { results were } \\
\text { reported/included } \\
\text { in the meta-analysis }\end{array}$ \\
\hline Lamy and colleagues $(2012)^{\mathrm{E} 40}$ & RCT & 2375 off-pump, 2377 on-pump & $11 / 2006$ to $10 / 2011$ & Short term \\
\hline Lemma and colleagues $(2012)^{\mathrm{E} 41}$ & RCT & 208 off-pump, 203 on-pump & $12 / 2006$ to $4 / 2010$ & Short term \\
\hline Lamy and colleagues $(2013)^{\mathrm{E} 42}$ & RCT & 2375 off-pump, 2377 on-pump & $11 / 2006$ to $10 / 2011$ & $1 \mathrm{y}$ \\
\hline \multicolumn{5}{|c|}{ Risk-adjusted observational studies/adjustment technique } \\
\hline Hernandez and colleagues $(2001)^{\mathrm{E} 43}$ & $\begin{array}{l}\text { Multivariable regression, } \\
12 \text { risk factors }\end{array}$ & 1741 off-pump, 6126 on-pump & 1998 to 2000 & Short term \\
\hline Plomondon and colleagues $(2001)^{\mathrm{E} 44}$ & $\begin{array}{l}\text { Propensity adjustment, } \\
11 \text { risk factors }\end{array}$ & 680 off-pump, 1733 on-pump & $10 / 1997$ to $3 / 1999$ & Short term \\
\hline Chamberlain and colleagues $(2002)^{\mathrm{E} 45}$ & $\begin{array}{l}\text { Multivariable regression, } \\
13 \text { risk factors }\end{array}$ & 332 off-pump, 1238 on-pump & $4 / 1996$ to $12 / 2000$ & Short term \\
\hline Mack and colleagues $(2002)^{\mathrm{E} 46}$ & $\begin{array}{l}\text { Multivariable regression, } \\
23 \text { risk factors }\end{array}$ & 1929 off-pump, 10631 on-pump & $1 / 1995$ to $12 / 2000$ & Short term \\
\hline Sabik and colleagues $(2002)^{\mathrm{E} 47}$ & $\begin{array}{l}\text { Propensity matching, } \\
10 \text { risk factors }\end{array}$ & 406 off-pump, 406 on-pump & $1 / 1997$ to $6 / 2000$ & Short term \\
\hline Aldea and colleagues $(2003)^{\mathrm{E} 48}$ & $\begin{array}{l}\text { Multivariable regression, } \\
9 \text { risk factors }\end{array}$ & 1233 off-pump, 7169 on-pump & $1 / 1999$ to $12 / 2000$ & Short term \\
\hline Boening and colleagues $(2003)^{\mathrm{E} 49}$ & $\begin{array}{l}\text { Propensity matching, } \\
11 \text { risk factors }\end{array}$ & 72 off-pump, 97 on-pump & $1 / 1998$ to $12 / 2001$ & Short term, 2 y \\
\hline Sabik and colleagues (2004) & $\begin{array}{l}\text { Propensity matching, } \\
10 \text { risk factors }\end{array}$ & 406 off-pump, 406 on-pump & $1 / 1997$ to $7 / 2000$ & $\begin{array}{l}1 \mathrm{y} \\
2 \mathrm{y} \\
4 \mathrm{y}\end{array}$ \\
\hline Stamou and colleagues $(2004)^{\mathrm{E} 51}$ & $\begin{array}{l}\text { Propensity matching, } \\
14 \text { risk factors }\end{array}$ & 1833 off-pump, 1833 on-pump & $10 / 1998$ to $6 / 2001$ & Short term \\
\hline Calafiore and colleagues $(2005)^{\mathrm{E} 52}$ & $\begin{array}{l}\text { Propensity matching, } \\
36 \text { risk factors }\end{array}$ & 597 off-pump, 597 on-pump & $11 / 1994$ to $12 / 2001$ & $\begin{array}{c}\text { Short term, } \\
\begin{array}{c}1 \mathrm{y} \\
3 \mathrm{y} \\
6 \mathrm{y}\end{array}\end{array}$ \\
\hline Lamy and colleagues $(2005)^{\mathrm{E} 53}$ & $\begin{array}{l}\text { Propensity matching, } \\
14 \text { risk factors }\end{array}$ & 1233 off-pump, 1233 on-pump & $3 / 2001$ to $12 / 2002$ & Short term, 1 y \\
\hline Roscitano and colleagues $(2005)^{\mathrm{E} 54}$ & Matching, 20 risk factors & 87 off-pump, 87 on-pump & $5 / 2000$ to $5 / 2002$ & Short term \\
\hline Stamou and colleagues $(2005)^{\mathrm{E} 55}$ & $\begin{array}{l}\text { Propensity adjustment, } \\
12 \text { risk factors }\end{array}$ & 315 off-pump, 198 on-pump & $1 / 1 / 2000$ to $12 / 31 / 2000$ & Short term \\
\hline Williams and colleagues $(2005)^{\mathrm{E} 56}$ & $\begin{array}{l}\text { Propensity adjustment, } \\
13 \text { risk factors }\end{array}$ & 641 off-pump, 5026 on-pump & $1 / 1998$ to $9 / 2003$ & Short term \\
\hline Di Mauro and colleagues $(2007)^{\mathrm{E} 57}$ & $\begin{array}{l}\text { Propensity matching, } \\
17 \text { risk factors }\end{array}$ & 1069 off-pump, 1381 on-pump & $11 / 1994$ to $12 / 2001$ & Short term, $10 \mathrm{y}$ \\
\hline Hannan and colleagues $(2007)^{\mathrm{E} 58}$ & $\begin{array}{l}\text { Multivariable regression, } \\
12 \text { risk factors }\end{array}$ & 13889 off-pump, 35941 on-pump & 2001 to 2004 & Short term \\
\hline Ivanov and colleagues $(2008)^{\mathrm{E} 59}$ & $\begin{array}{l}\text { Propensity matching, } \\
18 \text { risk factors }\end{array}$ & 503 off-pump, 503 on-pump & 1996 to 2002 & Short term \\
\hline Lattouf and colleagues $(2008)^{\mathrm{E} 60}$ & $\begin{array}{l}\text { Propensity adjustment, } \\
40 \text { risk factors }\end{array}$ & 5667 off-pump, 7145 on-pump & 1997 to 2006 & $\begin{array}{l}1 \mathrm{y} \\
3 \mathrm{y} \\
5 \mathrm{y} \\
10 \mathrm{y}\end{array}$ \\
\hline $\mathrm{Li}$ and colleagues $(2008)^{\mathrm{E} 61}$ & $\begin{array}{l}\text { Propensity matching, } \\
40 \text { risk factors }\end{array}$ & 447 off-pump, 744 on-pump & $1 / 1999$ to $12 / 2003$ & Short term \\
\hline Puskas and colleagues $(2008)^{\mathrm{E} 62}$ & $\begin{array}{l}\text { Propensity adjustment, } \\
40 \text { risk factors }\end{array}$ & 5667 off-pump, 7145 on-pump & 1997 to 2006 & Short term \\
\hline Konety and colleagues $(2009)^{\mathrm{E} 63}$ & $\begin{array}{l}\text { Propensity adjustment, } \\
31 \text { risk factors }\end{array}$ & 26011 off-pump, 99344 on-pump & 2000 to 2004 & Short term \\
\hline
\end{tabular}




\begin{tabular}{|c|c|c|c|c|}
\hline & Study type & Cohort size & $\begin{array}{l}\text { Period during which } \\
\text { surgeries were } \\
\text { performed }\end{array}$ & $\begin{array}{c}\text { Time points at } \\
\text { which mortality } \\
\text { results were } \\
\text { reported/included } \\
\text { in the meta-analysis }\end{array}$ \\
\hline Maganti and colleagues (2009) ${ }^{\mathrm{E} 64}$ & $\begin{array}{l}\text { Propensity matching, } \\
18 \text { risk factors }\end{array}$ & 619 off-pump, 619 on-pump & 1996 to 2004 & Short term \\
\hline Brizzio and colleagues $(2010)^{\mathrm{E} 65}$ & $\begin{array}{l}\text { Propensity matching, } \\
12 \text { risk factors }\end{array}$ & 1379 off-pump, 1379 on-pump & $1 / 1998$ to $12 / 2007$ & Short term \\
\hline Emmert and colleagues $(2011)^{\mathrm{E} 66}$ & $\begin{array}{l}\text { Propensity adjustment, } \\
50 \text { risk factors }\end{array}$ & 2203 off-pump, 2111 on-pump & 1999 to 2009 & Short term \\
\hline Filardo and colleagues $(2011)^{\mathrm{E} 67}$ & $\begin{array}{l}\text { Propensity adjustment, } \\
22 \text { risk factors }\end{array}$ & 732 off-pump, 7349 on-pump & $1 / 1997$ to $12 / 2008$ & $\begin{array}{l}5 \mathrm{y} \\
10 \mathrm{y}\end{array}$ \\
\hline Marui and colleagues (Sept. 2012) ${ }^{\mathrm{E} 68}$ & $\begin{array}{l}\text { Propensity adjustment, } \\
33 \text { risk factors }\end{array}$ & 1091 off-pump, 1377 on-pump & $1 / 2000$ to $12 / 2002$ & Short term, $5 \mathrm{y}$ \\
\hline Bakaeen and colleagues $(2013)^{\mathrm{E} 69}$ & $\begin{array}{l}\text { Propensity matching, } \\
19 \text { risk factors }\end{array}$ & 8911 off-pump, 26733 on-pump & $10 / 1997$ to $4 / 2011$ & $\begin{array}{l}1 \mathrm{y} \\
3 \mathrm{y} \\
5 \mathrm{y} \\
10 \mathrm{y}\end{array}$ \\
\hline Polomsky and colleagues $(2013)^{\mathrm{E} 70}$ & $\begin{array}{l}\text { Multivariable regression, } \\
31 \text { risk factors }\end{array}$ & 186138 off-pump, 689943 on-pump & $1 / 2005$ to $12 / 2010$ & Short term \\
\hline Bakaeen et al (2014) ${ }^{\mathrm{E} 71}$ & $\begin{array}{l}\text { Propensity matching, } \\
19 \text { risk factors }\end{array}$ & 11629 off-pump, 53468 on-pump & $10 / 1997$ to $4 / 2011$ & Short term \\
\hline Raja et al (2014) ${ }^{\mathrm{E} 72}$ & $\begin{array}{l}\text { Propensity matching, } \\
26 \text { risk factors }\end{array}$ & 307 off-pump, 397 on-pump & $1 / 2002$ to $12 / 2002$ & $\begin{array}{l}5 \mathrm{y} \\
10 \mathrm{y}\end{array}$ \\
\hline Moss et al (2015) ${ }^{\mathrm{E} 73}$ & $\begin{array}{l}\text { Multivariable regression, } \\
33 \text { risk factors }\end{array}$ & 9550 off-pump, 2529 on-pump & $1 / 2002$ to $7 / 2013$ & Short term \\
\hline
\end{tabular}

$R C T$, Randomized controlled trial. 


\section{E-References}

E1. Vural KM, Tasdemir O, Karagoz H, Emir M, Tarcan O, Bayazit K. Comparison of the early results of coronary artery bypass grafting with and without extracorporeal circulation. Thorac Cardiovasc Surg. 1995;43:320-5.

E2. Ascione R, Lloyd CT, Gomes WJ, Caputo M, Bryan AJ, Angelini GD. Beating versus arrested heart revascularization: evaluation of myocardial function in a prospective randomized study. Eur J Cardiothorac Surg. 1999; $15: 685-90$

E3. Czerny M, Baumer H, Kilo J, Zuckermann A, Grubhofer G, Chevtchik O, et al. Complete revascularization in coronary artery bypass grafting with and without cardiopulmonary bypass. Ann Thorac Surg. 2001;71:165-9.

E4. van Dijk D, Nierich AP, Jansen EW, Nathoe HM, Suyker WJ, Diephuis JC, et al. Early outcome after off-pump versus on-pump coronary bypass surgery: results from a randomized study. Circulation. 2001;104:1761-6.

E5. Angelini GD, Taylor FC, Reeves BC, Ascione R. Early and midterm outcome after off-pump and on-pump surgery in Beating Heart Against Cardioplegic Arrest Studies (BHACAS 1 and 2): a pooled analysis of two randomised controlled trials. Lancet. 2002;359:1194-9.

E6. Tang AT, Knott J, Nanson J, Hsu J, Haw MP, Ohri S. A prospective randomized study to evaluate the renoprotective action of beating heart coronary surgery in low risk patients. Eur J Cardiothorac Surg. 2002;22:118-23.

E7. Carrier M, Perrault LP, Jeanmart H, Martineau R, Cartier R, Page P. Randomized trial comparing off-pump to on-pump coronary artery bypass grafting in high-risk patients. Heart Surg Forum. 2003;6:E89-92.

E8. Lee JD, Lee SJ, Tsushima WT, Yamauchi H, Lau WT, Popper J, et al. Benefits of off-pump bypass on neurologic and clinical morbidity: a prospective randomized trial. Ann Thorac Surg. 2003;76:18-25; discussion 26.

E9. Muneretto C, Bisleri G, Negri A, Manfredi J, Metra M, Nodari S, et al. Offpump coronary artery bypass surgery technique for total arterial myocardial revascularization: a prospective randomized study. Ann Thorac Surg. 2003; 76:778-82; discussion 783

E10. Nathoe HM, van Dijk D, Jansen EW, Suyker WJ, Diephuis JC, van Boven WJ, et al. A comparison of on-pump and off-pump coronary bypass surgery in lowrisk patients. N Engl J Med. 2003;348:394-402.

E11. Chen X, Xu M, Shi HW, Mu XW, Chen ZQ, Qiu ZB. Comparative study of onpump and off-pump coronary bypass surgery in patients with triple-vessel coronary artery disease. Chin Med J (Engl). 2004;117:342-6.

E12. Gerola LR, Buffolo E, Jasbik W, Botelho B, Bosco J, Brasil LA, et al. Off-pump versus on-pump myocardial revascularization in low-risk patients with one or two vessel disease: perioperative results in a multicenter randomized controlled trial. Ann Thorac Surg. 2004;77:569-73.

E13. Legare JF, Buth KJ, King S, Wood J, Sullivan JA, Hancock Friesen C, et al. Coronary bypass surgery performed off pump does not result in lower in-hospital morbidity than coronary artery bypass grafting performed on pump. Circulation. 2004; 109:887-92.

E14. Nathoe HM, Buskens E, Jansen EW, Suyker WJ, Stella PR, Lahpor JR, et al. Role of coronary collaterals in off-pump and on-pump coronary bypass surgery. Circulation. 2004;110:1738-42.

E15. Straka Z, Widimsky P, Jirasek K, Stros P, Votava J, Vanek T, et al. Off-pump versus on-pump coronary surgery: final results from a prospective randomized study PRAGUE-4. Ann Thorac Surg. 2004:77:789-93.

E16. Velissaris T, Tang AT, Murray M, Mehta RL, Wood PJ, Hett DA, et al. A prospective randomized study to evaluate stress response during beating-heart and conventional coronary revascularization. Ann Thorac Surg. 2004;78:506-12; discussion 512.

E17. Wan IY, Arifi AA Wan S, Yip JH, Sihoe AD, Thung KH, et al. Beating heart revascularization with or without cardiopulmonary bypass: evaluation of inflammatory response in a prospective randomized study. J Thorac Cardiovasc Surg. 2004; 127:1624-31.

E18. Staton GW, Williams WH, Mahoney EM, Hu J, Chu H, Duke PG, et al. Pulmonary outcomes of off-pump vs on-pump coronary artery bypass surgery in a randomized trial. Chest. 2005;127:892-901.

E19. Lingaas PS, Hol PK, Lundblad R, Rein KA, Mathisen L, Smith HJ, et al. Clinical and radiologic outcome of off-pump coronary surgery at 12 months followup: a prospective randomized trial. Ann Thorac Surg. 2006;81:2089-95.

E20. Paparella D, Galeone A, Venneri MT, Coviello M, Scrascia G, Marraudino N, et al. Activation of the coagulation system during coronary artery bypass grafting: comparison between on-pump and off-pump techniques. J Thorac Cardiovasc Surg. 2006;131:290-7.

E21. Tatoulis J, Rice S, Davis P, Goldblatt JC, Marasco S. Patterns of postoperative systemic vascular resistance in a randomized trial of conventional on-pump versus off-pump coronary artery bypass graft surgery. Ann Thorac Surg. 2006;82:1436-44.

E22. Hernandez F Jr, Brown JR, Likosky DS, Clough RA, Hess AL, Roth RM et al. Neurocognitive outcomes of off-pump versus on-pump coronary artery bypass: a prospective randomized controlled trial. Ann Thorac Surg. 2007;84:1897-903.

E23. Karolak W, Hirsch G, Buth K, Legare JF. Medium-term outcomes of coronary artery bypass graft surgery on pump versus off pump: results from a randomized controlled trial. Am Heart J. 2007;153:689-95.

E24. Motallebzadeh R, Bland JM, Markus HS, Kaski JC, Jahangiri M. Neurocognitive function and cerebral emboli: randomized study of on-pump versus offpump coronary artery bypass surgery. Ann Thorac Surg. 2007;83:475-82.

E25. van Dijk D, Spoor M, Hijman R, Nathoe HM, Borst C, Jansen EW, et al. Cognitive and cardiac outcomes 5 years after off-pump vs on-pump coronary artery bypass graft surgery. JAMA. 2007;297:701-8.

E26. Bednar F, Osmancik P, Vanek T, Mocikova H, Jares M, Straka Z, et al. Platelet activity and aspirin efficacy after off-pump compared with on-pump coronary artery bypass surgery: results from the prospective randomized trial PRAGUE 11-Coronary Artery Bypass and REactivity of Thrombocytes (CABARET). $J$ Thorac Cardiovasc Surg. 2008;136:1054-60.

E27. Medved I, Anic D, Zrnic B, Ostric M, Saftic I. Off-pump versus on-pump-intermittent aortic cross clamping-myocardial revascularisation: single center expirience. Coll Antropol. 2008;32:381-4.

E28. Nogueira CR, Hueb W, Takiuti ME, Girardi PB, Nakano T, Fernandes F, et al. Quality of life after on-pump and off-pump coronary artery bypass grafting surgery. Arq Bras Cardiol. 2008;91:217-22. 238-4.

E29. Angelini GD, Culliford L, Smith DK, Hamilton MC, Murphy GJ, Ascione R, et al. Effects of on- and off-pump coronary artery surgery on graft patency, survival, and health-related quality of life: long-term follow-up of 2 randomized controlled trials. J Thorac Cardiovasc Surg. 2009;137:295-303.

E30. Shroyer AL, Grover FL, Hattler B, Collins JF, McDonald GO, Kozora E, et al. On-pump versus off-pump coronary-artery bypass surgery. $N$ Engl J Med. 2009; 361:1827-37

E31. Hueb W, Lopes NH, Pereira AC, Hueb AC, Soares PR, Favarato D, et al. Fiveyear follow-up of a randomized comparison between off-pump and on-pump stable multivessel coronary artery bypass grafting. The MASS III Trial. Circulation. 2010;122:S48-52.

E32. Mantovani V, Kennergren C, Bugge M, Sala A, Lonnroth P, Berglin E. Myocardial metabolism assessed by microdialysis: a prospective randomized study in on- and off-pump coronary bypass surgery. Int J Cardiol. 2010;143:302-8.

E33. Moller CH, Perko MJ, Lund JT, Andersen LW, Kelbaek H, Madsen JK, et al. No major differences in 30-day outcomes in high-risk patients randomized to offpump versus on-pump coronary bypass surgery: the best bypass surgery trial. Circulation. 2010;121:498-504.

E34. Serrano CV Jr, Souza JA, Lopes NH, Fernandes JL, Nicolau JC, Blotta MH, et al. Reduced expression of systemic proinflammatory and myocardial biomarkers after off-pump versus on-pump coronary artery bypass surgery: a prospective randomized study. J Crit Care. 2010;25:305-12.

E35. Sousa Uva M, Cavaco S, Oliveira AG, Matias F, Silva C, Mesquita A, et al. Early graft patency after off-pump and on-pump coronary bypass surgery: a prospective randomized study. Eur Heart J. 2010;31:2492-9.

E36. Michaux I, Filipovic M, Skarvan K, Bolliger D, Schumann R, Bernet F, et al. A randomized comparison of right ventricular function after on-pump versus offpump coronary artery bypass graft surgery. J Thorac Cardiovasc Surg. 2011; 141:361-7.

E37. Moller CH, Perko MJ, Lund JT, Andersen LW, Kelbaek H, Madsen JK, et al. Three-year follow-up in a subset of high-risk patients randomly assigned to off-pump versus on-pump coronary artery bypass surgery: the Best Bypass Surgery trial. Heart. 2011;97:907-13.

E38. Puskas JD, Williams WH, O’Donnell R, Patterson RE, Sigman SR, Smith AS, et al. Off-pump and on-pump coronary artery bypass grafting are associated with similar graft patency, myocardial ischemia, and freedom from reintervention: long-term follow-up of a randomized trial. Ann Thorac Surg. 2011;91: 1836-42; discussion 1842-3.

E39. Houlind K, Kjeldsen BJ, Madsen SN, Rasmussen BS, Holme SJ, Nielsen PH et al. On-pump versus off-pump coronary artery bypass surgery in elderly patients: results from the Danish on-pump versus off-pump randomization study. Circulation. 2012;125:2431-9.

E40. Lamy A, Devereaux PJ, Prabhakaran D, Taggart DP, Hu S, Paolasso E, et al Off-pump or on-pump coronary-artery bypass grafting at 30 days. $N$ Engl J Med. 2012;366:1489-97. 
E41. Lemma MG, Coscioni E, Tritto FP, Centofanti P, Fondacone C, Salica A, et al. On-pump versus off-pump coronary artery bypass surgery in high-risk patients: operative results of a prospective randomized trial (on-off study). J Thorac Cardiovasc Surg. 2012;143:625-31.

E42. Lamy A, Devereaux PJ, Prabhakaran D, Taggart DP, Hu S, Paolasso E, et al. Effects of off-pump and on-pump coronary-artery bypass grafting at 1 year. N Engl J Med. 2013;368:1179-88.

E43. Hernandez F, Cohn WE, Baribeau YR, Tryzelaar JF, Charlesworth DC, Clough RA, et al. In-hospital outcomes of off-pump versus on-pump coronary artery bypass procedures: a multicenter experience. Ann Thorac Surg. 2001;72: 1528-33; discussion 1533-34.

E44. Plomondon ME, Cleveland JC Jr, Ludwig ST, Grunwald GK, Kiefe CI, Grover FL, et al. Off-pump coronary artery bypass is associated with improved risk-adjusted outcomes. Ann Thorac Surg. 2001;72:114-9.

E45. Chamberlain MH, Ascione R, Reeves BC, Angelini GD. Evaluation of the effectiveness of off-pump coronary artery bypass grafting in high-risk patients: an observational study. Ann Thorac Surg. 2002;73:1866-73.

E46. Mack M, Bachand D, Acuff T, Edgerton J, Prince S, Dewey T, et al. Improved outcomes in coronary artery bypass grafting with beating-heart techniques. $J$ Thorac Cardiovasc Surg. 2002;124:598-607.

E47. Sabik JF, Gillinov AM, Blackstone EH, Vacha C, Houghtaling PL, Navia J, et al. Does off-pump coronary surgery reduce morbidity and mortality? J Thorac Cardiovasc Surg. 2002;124:698-707.

E48. Aldea GS, Goss JR, Boyle EM Jr, Quinton RR, Maynard C. Use of off-pump and on-pump CABG strategies in current clinical practice: the Clinical Outcomes Assessment Program of the state of Washington. J Card Surg. 2003; 18:206-15; discussion 216.

E49. Boening A, Friedrich C, Hedderich J, Schoettler J, Fraund S, Cremer JT. Early and medium-term results after on-pump and off-pump coronary artery surgery: a propensity score analysis. Ann Thorac Surg. 2003;76:2000-6.

E50. Sabik JF, Blackstone EH, Lytle BW, Houghtaling PL, Gillinov AM, Cosgrove DM. Equivalent midterm outcomes after off-pump and on-pump coronary surgery. J Thorac Cardiovasc Surg. 2004;127:142-8.

E51. Stamou SC, Jablonski KA, Garcia JM, Boyce SW, Bafi AS, Corso PJ. Operative mortality after conventional versus coronary revascularization without cardiopulmonary bypass. Eur J Cardiothorac Surg. 2004;26:549-53.

E52. Calafiore AM, Di Giammarco G, Teodori G, Iaco AL, Pano M, Contini M, et al. Bilateral internal thoracic artery grafting with and without cardiopulmonary bypass: six-year clinical outcome. J Thorac Cardiovasc Surg. 2005; 130:340-5.

E53. Lamy A, Farrokhyar F, Kent R, Wang X, Smith KM, Mullen JC, et al. The Canadian off-pump coronary artery bypass graft registry: a one-year prospective comparison with on-pump coronary artery bypass grafting. Can J Cardiol. 2005;21:1175-81

E54. Roscitano A, Benedetto U, Capuano F, Simon C, Tonelli E, Ruvolo G, et al. Offpump versus on-pump coronary artery bypass: does number of grafts performed represent a selection bias in comparative studies? Results from a matched cohort comparison. Ital Heart J. 2005;6:740-4.

E55. Stamou SC, Jablonski KA, Hill PC, Bafi AS, Boyce SW, Corso PJ. Coronary revascularization without cardiopulmonary bypass versus the conventional approach in high-risk patients. Ann Thorac Surg. 2005;79:552-7.

E56. Williams ML, Muhlbaier LH, Schroder JN, Hata JA, Peterson ED, Smith PK, et al. Risk-adjusted short- and long-term outcomes for on-pump versus offpump coronary artery bypass surgery. Circulation. 2005;112:I366-70.

E57. Di Mauro M, Gagliardi M, Iaco AL, Contini M, Bivona A, Bosco P, et al. Does off-pump coronary surgery reduce postoperative acute renal failure? The importance of preoperative renal function. Ann Thorac Surg. 2007;84: 1496-502.

E58. Hannan EL, Wu C, Smith CR, Higgins RS, Carlson RE, Culliford AT, et al. Offpump versus on-pump coronary artery bypass graft surgery: differences in short-term outcomes and in long-term mortality and need for subsequent revascularization. Circulation. 2007;116:1145-52.

E59. Ivanov J, Borger MA, Tu JV, Rao V, David TE. Mid-term outcomes of off-pump versus on-pump coronary artery bypass graft surgery. Can J Cardiol. 2008;24: 279-84.

E60. Lattouf OM, Thourani VH, Kilgo PD, Halkos ME, Baio KT, Myung R, et al. Influence of on-pump versus off-pump techniques and completeness of revascularization on long-term survival after coronary artery bypass. Ann Thorac Surg. 2008;86:797-805.

E61. Li Y, Zheng Z, Hu S. Early and long-term outcomes in the elderly: comparison between off-pump and on-pump techniques in 1191 patients undergoing coronary artery bypass grafting. J Thorac Cardiovasc Surg. 2008; 136:657-64.

E62. Puskas JD, Kilgo PD, Lattouf OM, Thourani VH, Cooper WA, Vassiliades TA, et al. Off-pump coronary bypass provides reduced mortality and morbidity and equivalent 10-year survival. Ann Thorac Surg. 2008;86:1139-46; discussion 1146.

E63. Konety SH, Rosenthal GE, Vaughan-Sarrazin MS. Surgical volume and outcomes of off-pump coronary artery bypass graft surgery: does it matter? $J$ Thorac Cardiovasc Surg. 2009; 137:1116-23.e1.

E64. Maganti M, Rao V, Cusimano RJ. Sex differences in resource use after on-pump and off-pump coronary artery bypass surgery: a propensity score-matched cohort. Can J Cardiol. 2009;25:e151-6.

E65. Brizzio ME, Zapolanski A, Shaw RE, Sperling JS, Mindich BP. Stroke-related mortality in coronary surgery is reduced by the off-pump approach. Ann Thorac Surg. 2010;89:19-23.

E66. Emmert MY, Seifert B, Wilhelm M, Grunenfelder J, Falk V, Salzberg SP. Aortic no-touch technique makes the difference in off-pump coronary artery bypass grafting. J Thorac Cardiovasc Surg. 2011;142:1499-506.

E67. Filardo G, Grayburn PA, Hamilton C, Hebeler RF Jr, Cooksey WB, Hamman B Comparing long-term survival between patients undergoing off-pump and onpump coronary artery bypass graft operations. Ann Thorac Surg. 2011;92: 571-7; discussion 577-8.

E68. Marui A, Okabayashi H, Komiya T, Tanaka S, Furukawa Y, Kita T, et al. Benefits of off-pump coronary artery bypass grafting in high-risk patients. Circulation. 2012;126:S151-7.

E69. Bakaeen FG, Chu D, Kelly RF, Ward HB, Jessen ME, Chen GJ, et al. Performing coronary artery bypass grafting off-pump may compromise long-term survival in a veteran population. Ann Thorac Surg. 2013;95:1952-8; discussion 1959-60.

E70. Polomsky M, He X, O’Brien SM, Puskas JD. Outcomes of off-pump versus onpump coronary artery bypass grafting: impact of preoperative risk. $J$ Thorac Cardiovasc Surg. 2013;145:1193-8.

E71. Bakaeen FG, Chu D, Kelly RF, Holman WL, Jessen ME, Ward HB. Perioperative outcomes after on- and off-pump coronary artery bypass grafting. Tex Heart Inst J. 2014;41:144-51.

E72. Raja SG, Benedetto U, Chudasama D, Daley S, Husain M, Amrani M, et al. Long-term follow-up of off-pump and on-pump coronary artery bypass grafting. Innovations (Phila). 2014;9:122-9; discussion 129.

E73. Moss E, Puskas JD, Thourani VH, Kilgo P, Chen EP, Leshnower BG, et al. Avoiding aortic clamping during coronary artery bypass grafting reduces postoperative stroke. J Thorac Cardiovasc Surg. 2015;149:175-80. 